\title{
体位性起立性頻拍症候群（POTS；Postural Orthostatic
}

\section{Tachycardia Syndrome）: 臨床医のための最新知見}

\author{
ブレア P. グラブ
}

オ八イオ医科大学 心臟電気生理・ペースメーカー部門

長友 敏寿*, 安部 治彦 (訳)

産業医科大学医学部 第二内科学教室

要 旨： Head-up tilt 試験の普及により，再発性の失神および失神前駆症状が自律神経 調節障害による一過性の起立性低血圧と徐脈に起因することが明らかになり， 神経調節性失神 (neurally mediated syncope) として知られている。一方，こ れまでの研究で，血圧はさほど変化しないにもかかわらず，起立時に心拍数 が異常に増加し, 失神前駆症状・運動不耐性・疲労・ふらつき・眩暈などの 起立性不耐性を発現する大きな患者群があることがわかった．本障害は一般 に体位性起立性頻拍症候群 (POTS ; postural orthostatic tachycardia syndrome) として知られるようになった，明らかな原因は不明であるが，軽度の末梢自 律神経性ニューロパシー（部分的自律神経障害；partial dysautonomia）や $\beta$ 受容体過敏性（ $\beta$-receptor supersensitivity）が病態生理として示唆されている. POTS の診断には詳細な病歴調査と神経学的検查を含む理学的検査が必要で, 特に head-up tilt 試験における反応様式は重要である。本稿では，体位性起立 性頻拍症候群の歴史的背景, 臨床的特徵と診断, 治療法について概説する.

(2000年 5 月 12 日 受付, 2000 年 7 月 5 日 受理)

はじめに

自律神経性調節障害に基づく一過性の低血 圧と徐脈が，再発性失神㧍よび失神前駆症状 の原因であることが明らかになってきた [1]. Head-up tilt 試験の普及により，このような 自律神経性調節障害を誘発する信頼性の高い 診断方法が得られるようになったばかりでな
く,この障害の病態生理学をより深く理解す ることができるようになった。これまでの研 究の中で, 自律神経性緊張状態の多様性に応 じて低血圧の程度も多様であることが明らか になり，完全に意識を失うまでには至らなく ても，失神前駆症状や，ふらつき，眩暈，一 過性虚血性発作などを誘発するのに十分な低 血圧状態に陥ることが明らかにされた。さら

本論文は Grubb 博士の依頼を受け，本号掲載の “Idiopathis Postural Orthostatic Tachycardia Syndrome（POTS）:

Emerging Concepts for the Clinician”を和訳したものである.

*産業医臨床研修等指導教員 
に，それほど重度ではないが，体位性頻拍， 運動不耐性, 疲労, ふらつき, 眩暈, 目の前に 星が見えるなどの特徵を有する起立性不耐性 を発現する大きな患者群が存在することがわ かった [2].このような患者を詳細に調査し たところ, 病歴, 理学的所見, 体位変化に対 する反応が本質的に同一であることが明らか になり，本障害は一般に体位性起立性頻拍症 候群 (POTS ; postural orthostatic tachycardia syndrome）として知られるようになった。本論 文では,これら患者の臨床的な特徵, head-up tilt 試験時の反応，治療法について概説する.

\section{歴史的背景と病因}

19世紀の初め, 明らかな原因が認められな いのにもかかわらず疲労や運動不耐性に苦し む患者(長時間床につくなど)がいることが報 告された。最初の報告のいくつかは, DaCosta による米国南北戦争の報告書である，彼は， この病態を表現するのに，「過敏性心臓症候 群 ; irritable heart syndrome」や「兵士の心蔵； soldier's heart」という語を使用した $[3]$. 第 一次世界大戦までには，このような症状は神 経調節性障害により，末梢血流が十分に調節 できない状態に至るという概念に基づき,「神 経循環無力症; neurocirculatory asthenia」あ るいは「血管調節性無力症； vasoregulatory asthenia」などの名称で多数報告された [4]. 1944年に MacLean らは，血圧は中等度しか 低下しないが心悸六進，ふらつき，脱力感， 運動不酎性などの愁訴があり起立性頻拍を発 現する患者群について報告し, 病態生理とし て，毛細血管レベルに扮ける障害のため心臓 へ戻る静脈血が減少するとの仮説を立てた [5]．1960年代には Frolich らが，極度の体位 性不安, 失神前駆症状および眩暈を訴える起 立性頻拍（低血圧を伴わないが，起立時に40 拍/分以上脈拍が増加）患者 2 例について報 告した [6]. 両患者ともイソプロテレノール
静注に心拍数が過度に反応し， $\beta$ 遮断薬の投 与により症状が改善した。1982年には, Rosen \& Cryer が起立時に心拍数が44拍/分以上増 大し(起立性低血圧を伴わない), 疲労, 運 動不耐性，心悸え進といった愁訴のある患者 を表現するのに「体位性頻拍症候群；POTS」 という語を使用した [7]. その少し後, Fouad らは体位性頻拍を発現するが低血圧は軽度で しかない起立不耐性患者の報告で，患者の症 状を「特発性血液量減少; idiopathic hypovolemia」と記述した [8]. その後, Streeten らが, 同じように低血圧を伴わない起立性頻拍患者 について報告した [9].テクネシウム $99 \mathrm{~mm}$ 標識赤血球のガンマカメラ計数を行って，仰 臥位時と起立時の患者のふくらはぎ領域を検 查したところ，下肢に極度の重力依存性静脈 貯留が認められた。面白いことに，症状は軍 隊抗ショックズボン (MAST ; military anti-shock trousers）を膨らませると，患者の心拍数は 正常に戻り，起立時に $45 \mathrm{~mm} / \mathrm{Hg}$ まで症状が 緩和した。その後, Streetenは，ノルアドレ ナリン注入にも過敏性を示寸同様の患者 4 例 の報告を行った [10]．Hoeldtkeらは体位性 頻拍の徵候を示し，失神前駆症状，運動不耐 性, 疲労, 認知障害を示す患者合計13例につ いて報告した。また彼らは，内臓血管収縮性 作用薬であるオクテロサイドはジヒドロエル ゴタミンよりも優れた治療効果を示すことを 明らかにした $[11,12]$ 。これは，内臓血管構 造も起立性血液貯留に重要であることを示唆 している．Lowらと Schondorf らは，極度の 疲労，運動不耐性，失神前駆症状，眩暈，腸 運動性減弱患者16例を総合的に分析したとこ ろ，これら患者の多くは慢性不安や恐慌発作 などの心理的問題を抱えることがわかった [13,14]. Head-up tilt 試験では，このような 患者は異常な心血管反応を示し, 多くの場合, 起立姿勢をとってから 2 分間以内に心拍数が 120-170拍/分にまで上昇した，患者の中に 
は，血圧が軽度に低下する患者もいたが，ほ とんどは正常血圧であり，中には高血圧を示 す患者もいた（拡張期血圧が $50 \mathrm{~mm} / \mathrm{Hg}$ 以下 の上昇を示す)。

以上のような症状を表わすのにしばしば体 位性起立性頻拍症候群（POTS）という名称 が使用され，自律神経障害の軽度のものだと 考えられている. Khuranaは, 同様の症状と tilt 試験での反応を示し，神経調節障害によ り下肢の汗腺の活性が低下している患者 8 例 について報告した [15]. Grubbらは最初, 極度の疲労, ふらつき, 起立性頻拍, 運動不 耐性, 認知障害, 失神前駆症状を示す患者 28 例について報告した [2]. Head-up tilt 試験 では, 各患者の心拍数は検査開始から 10 分以 内に最低30拍/分上昇した(各症例とも110拍/ 分以上)。立位時には収縮期血压は約 $20 \mathrm{~mm} /$ $\mathrm{Hg}$ の軽度の低下を示した $(85-90 \mathrm{~mm} / \mathrm{Hg}$ 以下になった患者はいなかった). その後,

Karasらは，同様の愁訴があり，同様の tilt 試験結果を示寸青年患者35例について報告し た [16].これらの報告から，この障害は小 児から高齢者までの広範囲な年齢の患者に影 響を与えると考えられる。

最近，循環血液量の減少がこのような障害 に重要な役割を果たすことが示唆されている [17]。これは，腎蔵のエリスロポイエチン産 生細胞の自律神経性調節障害により赤血球量 の低下に対するエリスロポイエチンの正常な 反応が損なわれているためと考えられる [18]. 組み換え型エリスロポイエチンを投与 すると，患者の中には劇的な改善を示す者が おり, 赤血球量が病態生理学的因子であると の考えを裏付けている [19].

POTS 患者は慢性疲労症候群と誤診されて いる可能性があることが次第に明らかになっ てきた [20]. 確かに，成人患者でも小児患 者でも，POTS と慢性疲労症候群の間には多 数の重なる部分がある可能性がある $[21,22]$.
面白いことに，このような症候群はどちらも ウイルス感染後に発現することが多く，この ような患者の中には免疫学的機序が関与する 者がいるのではないかとの疑問が生じること になった，注目すべき事柄として，POTS 患 者の中には, inappropriate sinus tachycardia と 誤診されている患者がいることである。この ような患者が洞結節の高周波カテーテルアブ レーションを受けると，一見洞性頻拍は消失 するものの，その後深刻な起立性低血圧が生 じてくる.

\section{定義}

色々な名称がこの現象を表わすのに作り出 されたが，表現が適確で覚えやすいことから， 我々は体位性起立性頻拍症候群（POTS）を 使用している，患者は起立時に症状が発現す るが臥位では緩和する起立性不耐性を特徵と する.POTS 患者はしばしば疲労, 運動不耐 性，ふらつき，悪心，集中力および記憶力低 下，振戦，再発性失神前駆症状（時には失神） を訴える。このような患者は恐慌発作あるい は慢性不安と誤診されることがしばしばある。 シャワー（時には食事でさえ）のような中等 度の労作で症状を増長することがあり, 日常 の軽度な活動さえ著しく制限されることがあ る。重度の自律神経不全ではないので，一般 的な理学的検査では診断がつかず，患者はし ばしば「どこも悪いところはありません」と 言われる。

現在, POTS とは, 起立あるいは直立になっ てから 10 分以内に心拍数が少なくとも 30 拍/ 分増加するか, 120 拍/分以上になる起立性症 状の発現と定義される. POTS 患者の年齢範 囲 (10-60歳)では，心拍数のこの上昇は1083歳の対照被験者に対しては99パーセンタイ ルを超える [23]. 心拍数が最も客観性の高 い起立性不耐性の測定指標であるが，血圧， 洞性頻拍, 疲労, 血管運動症状を示す非起立 
性の自律神経調節障害を考慮する必要がある。

\section{臨 床 的 特 徵}

POTS 患者の大半は（10歳や70歳の患者も 見られるが） 15-50歳である，症状が発現す るまでの平均的な期間は約 1 年だと思われる。 最も一般的な発現症状は心悸立進, 疲労, ふ らつき，運動不耐性，振戦，下肢筋力低下で ある。それほど多くはないが，悪心，胸痛， 過換気, 不安, 認知障害, 胃アトニー, 頭痛 の訴えもある。患者の大半は女性で，女性対 男性の比率は 5 対 1 と報告されている（男性 に比べ女性は医学的援助を求める傾向がしば しば高いので，来院にある程度の偏りがある と考えられる）[24].

前述したように，本障害に関するどの報告 書でもほぼ半数の患者は発熱性疾患（ウイル ス性であると思われる）罹患後に症状が発現 している。このため，患者の中には免疫学的 機序が発生に関与している患者がいることが 示唆されている $[2,24]$. 多くの自律神経調 節不全の発生率は女性の方が高いが，これも， POTSの性差を説明する一つであると思われ る，手術，外傷，妊張などの様々なストレス の後で症状が発症する患者もいる。また,「い つも同じょうにやっているのに」と言ってい るにもかかわらず，症状は次第に悪化する患 者もいる，興味深いことに，症状が周期的に 発現する患者が扔り，多くの女性は月経期直 前に症状が増悪する。また，著明な改善期間 後に数日間症状が強まる患者がいる．興味深 い愁訴の一つとして，安静時に症状発現が強 $<$, 軽度洞性頻拍（心拍数110-130拍/分） と強い疲労が伴うことがある。大量の摂取に もかかわらず体液垜失が激しい期間があると 訴える患者がいるが，このような症例では時 折，重度の低血圧をきたすため点滴補液が必 要な場合がある。

\section{分 類}

POTS の病因はまだ明らかにされていない が，臨床的特徵は類似するが種類が異なる障 害群が存在すると考えるのが最も妥当だと思 われる[15]。第 1 の患者群は，軽度の特発 性末梢自律神経性ニューロパシー（部分的自 律神経障害; partial dysautomia) であり, 起 立時に末梢血管抵抗を増大させる能力がない ため，過度の代償性体位性頻拍が発現する。 静脈貯留の存在により心室前負荷が低下し, 起立時に圧受容器脱負荷となり，交感神経性 刺激が増大することになる $[9,10]$. Furlan らは,このような患者に micro neurography を 用いて，平均交感神経活性と共に心拍変動を 調査し, 安静時と起立に対する節後交感神経 反応によってノルアドレナリン緊張が総合的 に増強されることを明らかにした（代償性心 蔵交感神経系過剩活性; compensatory cardiac sympathetic over-activity）［25．これら患者の 多くは長時間起立すると下肢が青みがかった 色に変色する $[2,9]$.

第 2 の患者群は, $\beta$ 受容体過敏性患者群 $(\beta-$ receptor supersensitivity）である [24]. 別の 表現として過剩アドレナリン作動性起立性不 耐性 (hyperadrenergic orthostatic intolerance) という名称を使用する研究者もいる．多くの 患者は，起立時に心悸光進と頻拍に加え，極 度の振戦と不安を訴え，仰臥位時に低用量の イソプロテレノール注入に対し過剩反応を示 す $(1 \mu \mathrm{g} /$ 分のイソプロテレノール注入に対 して心拍数が30拍/分以上増加するのも稀で はない)。この過敏性が一次性なのか，ある いは二次性の denervation supersensitivityによ るものなのかは明らかではない。ほとんどの 患者は，過剩な交感神経活性化を示しており， この過剩な交感神経活性化は压反射機序では 弱めることはできない.Jacobらの行った最 近の研究で，このような患者は起立時にノル 
エピネフリンクリアランスが低下するばかり でなく, チラミンのノルエピネフリン放出効 果に抵抗性を示すことが報告されている [26]。アドレナリン作動性アゴニストに対す る著明な感受性増大とこのような所見から， POTS 患者の中には交感神経性心血管調節が 障害を受けている患者がいることが示唆され る。このような患者は部分的自律神経障害型 POTS と多くの共通する特徵を持つ一方で， 振戦，片頭痛様頭痛，冷感，下肢発汗を訴え ることが多く，これらを鎮静する試験が行わ れているところである.

「Secondary POTS」という名称は，末梢自 律神経障害があるにもかかわらず，心臟性調 節が保存されている場合に使用され，糖尿病， アミロイドーシス，シェーグレン症候群ある いはループス等に起因する自律神経障害があ る [24]。時には，pure autonomic failure ある いは multiple systems atrophyのようにより高 度な障害を示す患者もいる [27］。

\section{評価および治療}

まずは，詳細な病歴調査と神経学的検查を 含む理学的検査が必要である。また，貧血， 脱水あるいは慢性消耗性疾患のような起立性 不耐性の原因と考えられている疾患に対する 評価を行う，原因あるいは増悪因子と思われ る薬剤 (血管拡張剂，三環系抗うつ郕，MAO 阻害剤あるいはアルコール）を患者が服用し ているかどうかの確認も重要である。心拍数 と血圧は仰臥位時，座位，起立時において測 定する必要がある。心臟に原因が考えられる 時には，器質的心疾患について評価を行わな ければならない。体位には無関係に突然発症 する洞性頻拍が存在すれば，洞結節リエント リー性頻拍の可能性が示唆され, 電気生理学 的検査が必要である。

Head-up tilt 試験は，体位変化に対する標 準的な反応測定法として有用である [1]．患
者を tilt table の上に乗せ，仰臥位時の血圧と 心拍数を測定した後, 立位 $\left(70^{\circ}\right.$ 頭部を上げ た角度）に傾斜させ，1-2 分間隔で血圧と 心拍数を測定する. 受動立位にしてから 10 分 以内に心拍数が30拍/分以上増加するか，心 拍数が120拍/分以上になることを, POTSの 診断基準とする。必要があれば， $1 \mu \mathrm{g} /$ 分の イソプロテレノール静注に対する心拍数の反 応も測定する．心拍数が30拍/分以上増加す れば，異常と考える．POTS 患者は長く直立 姿勢にすると，低血圧と失神を伴う神経調節 性失神をきたす可能性がある。

一つの治療法が等しく成功するわけではな いので，患者の治療には試行錯誤が必要であ る，治療の第一段階は，可能性のある原因を すべて取り除くことである，糖尿病，極端な 体重減少，慢性消耗性疾患あるいは長期の運 動不足などや，服用している薬剤が原因とし て関係しているかどうかを明らかにしなけれ ばならない（患者によっては不正な薬郕の使 用が関係していることも考えなければならな い） [28]，患者とその家族にこの病気の性質 について説明し, 極度の脱水, 過剩なアルコー ル摂取などの増悪因子を避けるよう教育する ことは極めて重要な治療の一つである．患者 には塩分の掑取を増やしたり，頭部を少し高 くした状態で眠るよう勧める（ベッドの後部 支柱の下に赤レンガを置くと簡単に高くする ことができる)。軽度のエアロビクス運動も 有効で, 20分間のエアロビクス運動を少なく とも週 3 回行うことを最終目標とする。患者 の中にはこれよりもはるかに低レベルの運動 を非常にゆっくりと行わなければならない患 者もいるが，このような患者には水中運動が 耐容性に優れていると思われる。下肢を鍛え る抵抗性トレーニングは，骨格筋ポンプの作 用を増大させ，静脈還流を増大させるため， 特に有用である。弾性ストッキングも静脈販 留を低下させるので，患者によっては非常に 
有用である。この時，ストッキングをできる だけ高く上げ，〈るぶしの圧力を少なくとも $30 \mathrm{~mm} / \mathrm{Hg}$ にしなければならない.

薬物療法に関しては，ある患者に有効だか らといって別の患者にも有効であるとは限ら ないため, 患者ごとに薬物療法を調整しなけ ればならない，有用性が認められている薬剤 の一つにフルドロコルチゾン (fludrocortisone)がある.同薬の一般的な用量は $0.2 \mathrm{mg} /$ 日である．フルドロコルチゾンの有効性は適 切な塩分摂取に依存するということは重要な ことである。フルドロコルチゾンと共に塩分 表を渡すと役立つことがしばしばある。この 薬剂は低カリウム血症を誘発することがある ので，定期的に血清カリウムレベルをチェッ クしなければならない， $\alpha-1$ 受容体刺激剂で あるミドドリン (midodrine) は強力な血管 収縮歳であり，1日 3 回まで，2.5-20 $\mathrm{mg}$ を 経口投与すると通常, 症状が緩和する。ミド ドリンは「必要時」投与も可能である．時間 が経過すると同薬に対して tachyphylaxis を きたすため，再感作させるために「休薬療 法」を必要とする患者がいることに我々は気 づいた。過アドレナリン作動型 POTS 患者群 は $\beta$ アドレナリン作動性遮断薬によって改 善することがある（部分的自律神経障害型で はしばしば増悪する)。POTS 患者では疲労 が大きな問題であるため, 我々は血液脳関門 を通過しにくい $\beta$ 遮断薬を使うようにして いる，中枢性交感神経遮断薬は特定の患者に は有用であるが，患者によっては過度の感受 性を示す患者がいるため，ごく少量から投与 開始しなければならない。クロニジンは交感 神経節後線維が関与した患者の血圧と心拍数 を安定化させることができる [29]．このよ うな患者では，血管 $\alpha-2$ 受容体（静脈系全体 に多数存在する）が過敏となっており，血管 に対する中枢神経系の影響が低下するために， クロニジンは血管収縮効果を示す。利便性お
よび安定性の観点から，我々はしばしばクロ ニジンパッチを使用している，メチルドーパ を用いて成功したと報告している研究者もい る。過アドレナリン作動型 POTSに有用だと 報告されている中枢作用性薬剤としてフェノ バルビタールがあるが，依存症の問題がある ので慎重に使用しなければならない $[30]$. 自律神経障害患者の中には中枢でのセロトニ ン産生と調節が障害を受けている患者がいる ことが示唆されているが [31]，このような 患者には選択的セロトニン再吸収阻害剤は有 用ではある。我々はベンラファキシン (venlafaxine）が最も有効であることを明らかにし た．治療に抵抗性を示す患者には，組み換え 型エリスロポイエチンが有用かもしれない $[18,19]$. これは赤血球量を増加させること によって血管内容量を増加させるだけでなく， 直接的な血管収縮効果も持つと思われるが, 静注もしくは皮下注しなければならず，非常 に高価であることが欠点である，高用量の単 独療法よりも低用量薬の併用療法の方が有効 性が高いことがしばしばあり，様々な治療法 を組み合わせることが必要である．残念なが ら，どのような治療形態にも反応や耐容性を 示さない患者もいる．治療法の詳細について は他論文を参照されたい $[30,32]$ 。

\section{結論}

POTS は, 体位性頻拍, 心悸立進, 疲労, 運 動不耐性等を特徵とする起立性不耐性である が, 診断・治療は可能である。本疾患の重要 な点は, 健康な若年者に実質的な障害を誘発 するため，影響を受ける患者数が多いことで ある. 受動的立位により, 患者の心拍数は最 初の10分以内に 30 拍/分以上あるいは120拍/ 分以上の増加になり, 症状が出現する. 患者 の中にはイソプロテレノールに過剩反応を示 す者もいる．自律神経バランスを直接修正す る治療法によってしばしば症状を緩和するこ 
とができる．本症候群およびサブタイプの理 解を深め，患者を正常な生活に戻す治療法を 提供するためには一層の努力が必要である。 これらの研究の進展により, 起立性不耐性を
伴う自律神経障害やその他の自律神経障害に ついても洞察を深めることができるであろう [33].

Idiopathic Postural Orthostatic Tachycardia Syndrome（POTS） : Emerging Concepts for the Clinician (in Japanese)

\section{Blair P. GRUBB}

Cardiac Electrophysiology and Pacemaker Laboratory,

The Medical College of Ohio. Toledo, Ohio 43614-5809, U.S.A.

\section{Translated into Japanese by T NAGATOMO and H ABE}

The Second Department of Internal Medicine, School of Medicine, University of Occupational and Environmental Health, Japan. Yahatanishi-ku, Kitakyushu 807-8555, Japan

Abstract: Stimulated by the widespread use of head-up tilt testing, transient episodes of neurocardiogenically mediated hypotension and bradycardia have become a well recognized cause of recurrent syncope and near syncope (generally referred to as neurally mediated syncope). On the other hand, a large subgroup of patients was identified, who appeared to have a less severe hypotension and orthostatic intolerance that is characterized by postural tachycardia, exercise intolerance, disabling fatigue, lightheadedness and dizziness. This form of disability has been recognized as postural orthostatic tachycardia syndrome (POTS). While the etiology of POTS is still unclear, a mild form of idiopathic peripheral autonomic neuropathy (partial dysautonomia) or beta-receptor hypersensitivity has been suggested for the pathophysiology of this disorder. A detailed history and physical examination that includes a careful neurologic examination are essential for diagnosis. Head-up tilt testing is often useful as a standardized measure of response to postural change. This review summarizes the history, current knowledge of clinical features, diagnosis and therapeutic strategies.

Key words: orthostatic intolerance, autonomic dysfunction, syncope .

$$
\text { J UOEH } 22(3): 239-245(2000)
$$

